\title{
TRANSFORMATIONS OF HIGH MOUNTAIN PASTORAL STRATEGIES IN THE PAMIRIAN KNOT
}

\author{
Hermann Kreutzmann
}

\section{Abstract}

Mountain pastoralism in the Pamirian Knot has been significantly transformed from the nineteenth to the twentieth century. The development path has depended on spheres of influence of dominating powers and affiliation to mighty neighbours and, subsequently, to parties in the Cold War. Significant interventions that led to structural changes can be societal transformations, such as those that happened in the Emirate of BokharaTsarist Russia-Soviet Union-Tajikistan sequence, as well as in the framework of establishing Afghan dominance in Badakhshan, in postrevolutionary interventions in Chinese Xinjiang or in the integration of Karakoram communities in the newly created nation-state of Pakistan.

Keywords: Central Asia, Pamirs, transformation, mountain pastoralism, combined mountain agriculture

As we have seen, the mountains resist the march of history, with its blessings and its burdens, or they accept it only with reluctance. And yet life sees to it that there is constant contact between hill population and lowlands. None of the Mediterranean ranges resembles the impenetrable mountains to be found in the Far East, in China, Japan, Indochina, India, and as far as the Malacca peninsula. Since they have no communication with sea-level civilization, the communities found there are autonomous (Braudel 1972: 41).

\section{Introduction}

Phenomena observed in high mountain regions are regularly interpreted as the result of natural frame conditions rather than as the visible effects of human action and environmental construction. This perception is particularly encountered when mountain regions outside the industrialized world are in focus, as the above quotation from Fernand Braudel proves. Modernity for mountain areas has been defined by the extension of colonial interest into the mountain periphery. In the context of Central Asian mountains, colonial expansion highlights the focus on the innermost parts of the Eurasian landmass after the conquest of the coastal areas. Mountains, plateaux, deserts and highlands containing historical Silk Road 
settlements in fertile oases, stretched over a vast area with a meagre population density. The search for mineral wealth and agricultural output was never the driving force during the transformation from colonialism to imperialism. The latter was striving for territorial control, boundary making and administrative efficiency. Territorial appropriation meant in the first place the exclusion of other colonial players and the striving for the conqueror's sole autonomy. The philosophy of modernity was strongly embedded in an ethical justification of control and dominance, epitomized in Kipling's 'white man's burden' and Dostoyevsky's elaborations on the importance of Central Asia for Russia's future. Both colonial powers assumed a self-imposed mandate that aimed for modernization in the remote corners of the Eurasian landmass.

With missionary zeal and state authorization, civil society measures grounded in European standards were to be promoted in Asia. Kipling's Russian counterpart was Fyodor M. Dostoyevsky, who justified the Asian conquest as a mission for the promotion of civilization. The highly regarded Russian novelist compared the colonial expansion into Central Asia with the European conquest of North America (see also Hauner 1989, 1992; Sahni 1997). In both cases a superiority complex based on cultural and developmental sophistication supported the armed conquest and administrative, economic and social domination afterwards.

The lower end of social hierarchies was composed of nomadic tribes who previously had managed to evade strict control and followed a lifestyle which was perceived by the new masters as one of utmost backwardness. Strategic control of vast tracts of deserts and steppes necessitated a coming to terms with mobile groups and eventual domination over them. The second half of the nineteenth century saw a heated debate in political and academic circles about the effects of the AngloRussian rivalry in Central Asia.

In Russia, the Gorchakov Memorandum of 1865 marks the beginning of the animated phase of the 'Great Game'. In 1872, the British Premier Disraeli responded in his famous speech at Crystal Palace, in which he announced the imperial policies for further expansionism. Russia and Great Britain fought this game in the remote mountains of the Hindukush, Karakoram and Pamirs where their spies-cum-explorers met in unexpected locations. At the same time, there was competition among the diplomatic staff posted in Central Asian centres. Kashgar in particular became one of the hotspots of confrontation where a weak Chinese administration personified by a Taotai fell prey to the powerful representatives of the superpowers: the Russian Consul M. Petrovsky and his British counterpart George Macartney were the protagonists and reported to their respective governments in detailed reports (General Staff India 1907; Kuropatkin 1882; Skrine and Nightingale 1973). Their writings give us historical evidence on the socioeconomic conditions in Central Asia, along with strategic and military intelligence during their period of rivalry. Nomads were an uncertainty in their political equations, so control of their movements was the attempted solution for the future. 


\section{Pastoralists as Role Models of Backwardness - Ellsworth Huntington's Geographical Model of Civilization Contested}

When writing the introductory chapter on 'man's relation to physical environment' for 'principles of human geography', the eminent American geographer of the early twentieth century, Ellsworth Huntington, first developed a matrix of categories which he then applied to test areas. His personal Central Asian fieldwork experience (Huntington 1905, 1907) influenced his judgement to such an extent that he identified the Kirghiz nomads as the antipodes of Western civilization:

The nature of human geography may be illustrated by an example. Some of the Khirghiz of Central Asia are wandering herdsmen, or pastoral nomads, who live in the Great Tian Shan Plateau of Central Asia in summer, and descend to the valleys and the lowland plains in winter. They are densely ignorant and superstitious. So low are they in the scale of civilization that they know almost nothing of manufacturing, science or art ... They eat their meals with their fingers from the common dish, while sitting cross-legged on the bare ground or on the woolen rugs which are the most beautiful of their few manufactures ... According to our standards the Khirghiz are dirty, lazy, and unprogressive ... On the south the great deserts of Chinese Turkestan and the huge desolate plateau of Tibet separate the Khirghiz from India and all outside influences in that direction. On the east and west they are also shut in by deserts so that they come in contact only with nomads like themselves ... Only toward the north, where the desert is less severe, do the Khirghiz come in contact with a civilized people, the Russians, but even that contact is slight. Thus isolation is the keynote of the Khirghiz location (Huntington and Cushing 1924: 12).

Huntington applies a matrix that he himself developed: it is broadly classified in 'physical conditions', 'life' and 'human responses' and identifies the refined categories of judgement. Location and communication play a predominant role. Location gives the environmental properties to which the people seem to be bound, while isolation deters people from exchange and communication. The environmental properties are limited: 'In such an environment what mode of life should we expect? ... Since grass is the chief resource the best way is to keep domestic animals such as sheep, cows, horses, or camels ... Hence the most practicable mode of life is pastoral nomadism. That is, the Khirghiz must keep animals, and drive them from pasture to pasture ... lack of steadfastness, the difficulties of transportation, the isolation, and the lack of other incentives cause Khirghiz industries and commerce to be poorly developed' (Huntington and Cushing 1924: 15, 19).

Consequently, the Kirghiz feature prominently as non-modern people when it comes to progress: 'Among nomads like the Khirghiz education and science are even less developed than government ... The absence of contact with outside people 
and their own lack of inquisitiveness prevent the Khirghiz from making scientific discoveries... Thus civilization remains stationary. The Khirghiz are not savages, but the gulf between them and the more enlightened nations is growing wider. The influence of European civilization has begun to reach them, but their mode of life will probably change only a little so long as they depend chiefly upon grass of the plains and high plateaus' (Huntington and Cushing 1924: 21).

Many Kirghiz animal husbanders are still depending on the prime resource offered by the Central Asian plateaux and Pamirs - natural grazing - for the fodder supplies of their bovines and ovines. Nevertheless, since the travels of Ellsworth Huntington, great geopolitical changes have occurred.

What is the message of Ellsworth Huntington, who dragged the Kirghiz into the limelight of the introductory chapter of his influential geographic textbook more than eighty-five years ago? Somehow, his statement reflects a judgement then repeated for generations to come. Nomadism has been regarded as a backward 'mode of survival', and a low level of civilization has been attributed to such a strategy. Nomadism and pastoral livelihoods had to be surpassed in order to elevate the marginalized nomads through sedentarization (for further discussions of the span of arguments and case studies, see Barfield 1993; Humphrey and Sneath 1999; Scholz 2002, 2008). The Soviet Union and the People's Republic of China learnt from such suggestions and, under the directives and orders from Josef Stalin and Mao Zedong, implemented sedentarization programmes in Central Asia. Many other states supported similar programmes and strategies in the rest of the world. In development thought, there was not much difference between the First and the Second World when it came to ideas during the 1960s and 1970s on how to 'modernize' the Third World and their 'backward' inhabitants, who were supposedly driven by tradition alone.

\section{Pastoralists as the Target of Modernization}

Modernization of livestock-keeping sector aimed at the sedentarization of nomads, with permanent settlements seen as the physical expression of change and modernity. But such a narrow view of change neglects the transformation in other socio-political and economic sectors. Beginning during the Tsarist period, external influence grew. For the Russian-dominated Western Turkestan, the influence started early in the nineteenth century, whereas for the Chinese-dominated Eastern Turkestan, the major transformations took place in the second half of the twentieth century. In the northern part of British India and Kashmir, British domination had its major impact after 1935 when the Gilgit Agency was leased for sixty years from the Maharaja of Kashmir. At this time, the British Raj felt responsible for improving the living conditions. Despite all these different developments, there is some common ground in all attempts at modernization. Especially after the October Revolution and the formation of the Soviet Union in the 1920s and after the Chinese 
Revolution reached Xinjiang in the early 1950s, revolutionary zeal had a significant impact in the region. Every sphere of life was affected by social intervention in the name of communism. Traditional social hierarchies were abolished and replaced by party structures and cadre organizations. The provision of modern infrastructure such as schools, health posts, transport and basic goods for everyday needs was centrally organized and reached the most remote corners of the mountain areas. When this happened here, the Northern Areas of Pakistan as well as the Wakhan and Pamir regions of Afghanistan were devoid of any such activities. Therefore, it seems advisable to discuss first the role of remote mountain regions in the course of modernization. Minorities occupying the highland regions, plateaux and valley heads in the Western Kun Lun Shan, Pamir, Hindukush and Karakoram often feature as the last survivors of a pristine culture (Brower and Johnston 2007). The thesis put forward here is exactly the opposite: every corner of a given political system and/or nation-state is affected by decisions made at the centre.

\section{The Environmental Setting}

The Pamirian Knot is characterized by environmental conditions typical of high mountain valleys and plateaux. Altitude and aridity (Figure 1) cause thermal and hydrological natural thresholds for farming, which can be overcome at least partly by human action and innovation. Wakhi villages are located in an altitudinal range between 2,150 and 3,500 m. Arid and semi-arid conditions prevail, resulting in an



Figure 1: Climatic conditions in the Pamirs 
irrigated single-cropping agriculture (barley, wheat, potatoes, beans and peas) which is always supplemented by animal husbandry. With a few exceptions, vegetation coverage is sparse and forests are absent. A few fruit trees such as apple, apricot, walnut and mulberry are to be found and wood is taken from poplar plantations, a common sight in Central Asia. The specific attraction of this ecological belt is related to the availability of water stored in glaciers and snow.

Meltwater feeds the man-made irrigation systems for cultivation. Only Wakhi grow crops, while Kirghiz (in the study area) refrain from any form of settled agriculture. Both groups utilize high pastures where ground and running water allow seasonal meadows. Kirghiz grazing grounds are generally located above

Table 1: The system of Pamirs

\begin{tabular}{|c|c|}
\hline Eastern Pamir & $\begin{array}{l}\text { Gorno Badakhshanskaja Avtonomnaja Oblast (GBAO) } \\
\text { Republic of Tajikistan } \\
\text { - Khargushi Pamir (Pamir of the hare): } \\
\text { the basin of lake Kara Köl (black lake) } \\
\text { - Rang Köl Pamir (Pamir of the coloured lake): } \\
\text { the basin of the lake with the same toponym } \\
\text { - Sariz Pamir (Pamir of the yellow trail): } \\
\text { part of the Murghab valley up to the settlement of } \\
\text { Murghab (previously named Pamirski Post) } \\
\text { - Alichur Pamir: the valley of the river with the same } \\
\text { toponym }\end{array}$ \\
\hline Wakhan & $\begin{array}{l}\text { Wakhan Woluswali, Badakhshan, Republic of Afghanistan } \\
\text { - Chong Pamir: Great Pamir or Pamir-e Kalan: } \\
\text { the headwaters of the Pamir Darya and the basin of Zor } \\
\text { Köl (big lake) } \\
\text { - Kichik Pamir: Little Pamir or Pamir-e Khurd: } \\
\text { the headwaters of the Aksu river including the lakes } \\
\text { Chakmaktin Köl and Besh Ötök Köl }\end{array}$ \\
\hline Warikol & $\begin{array}{l}\text { Taxkorgan Tajik Autonomous County } \\
\text { Uigur Autonomous Region Xinjiang, People's Republic } \\
\text { of China } \\
\text { - Taghdumbash Pamir: headwaters of the river with the } \\
\text { same name and the Karachukur river }\end{array}$ \\
\hline
\end{tabular}

Source: adapted from Kreutzmann (1996: 51) derived from Curzon (1896);

Dor and Naumann (1978: 25) 
3,500 m. Since Marco Polo, the belief in the high nutritional properties of the Pamir pastures prevails. Game from there such as Marco Polo sheep (Ovis ammon) and ibex (Capra ibex), and livestock (yaks, fat-tailed sheep and goats) gained fame as high quality meat among consumers in the low-lying Central Asian town oases along the Southern Silk Route.

The Wakhi term 'pamer' reflects the specificity of the fertile high mountain pastures and was taken as a defining feature to describe natural grazing grounds of substantial extent as 'Pamirs' (Table 1).

In addition to the seven extended Pamirs (up to 300 sq. $\mathrm{km}$ of pasture area each), some smaller Pamirs such as the Pamir-e Bugrumal (upper Gunt Valley, GornoBadakhshan), Mariang Pamir (Sarikol), Tagarma Pamir (Sarikol) and Shimshal Pamir (Northern Areas of Pakistan) may be added. Natural grazing is the major asset of the Pamirs, augmented by meagre cultivation.

The overall setting comprises three areas. The valley bottoms are mainly inhabited by Wakhi and other Pamirian mountain farmers who live in permanent villages and who seasonally access nearby pastures in the side-valleys. Above $3,500 \mathrm{~m}$, the main valleys widen and become flatter; this is where we find the extensive Pamir pastures. Both Wakhi and Kirghiz utilize these. Wakhi follow a pattern of retreat to their homesteads for the cold season, whereas the Kirghiz remain at the high altitudes. The third area is solely dominated by Kirghiz nomads. The high plateaux favour mobile pastoralists, as the distance to the permanent dwellings in the river valleys increases. Nevertheless, the growing demand for natural grazing and mutual dependency have resulted in abridged utilization patterns, mobility and political interference.

\section{Traditional Pasture Utilization Strategies}

The two major adaptive strategies of utilizing the pasture potential of Western High Asia are nomadic animal husbandry and in the livestock sector of combined mountain agriculture (see Ehlers and Kreutzmann 2000):

(i) Traditionally, nomadic groups were able to exploit natural resources at dispersed locations. Distances in the order of several hundred kilometres separated economically valuable mountain pastures from winter camp sites, with areas of less economic interest lying inbetween. With specific regard to the region under analysis functional migration cycles can be recognized: longer stays in high altitude pastures during summer alternate with winter grazing in low-lying basins in the northern foothills or plains of the Inner Asian mountain arc. In both areas, the nomads are dependent on being tolerated as a mobile group and being able to pay the grazing fees if applicable. 
(ii) Combined mountain agriculture has the advantage of simultaneous fodder production in the permanent homesteads for herds grazed in the high-lying pastures during the summer. The limiting factor here is the provision of up to nine months' feed, which has to be produced on private or common property village lands. Houses are usually located at the upper levels of permanent settlements in single crop farming areas. Access to the Pamir pastures involves shorter migrations and some mobility within the summer habitations. Fodder here is comparatively plentiful, but only available for a short period; feed storage and transport to the homesteads are of limited importance.

Both approaches can result in contests over common resources in the same location and have frequently been discussed as competing strategies when conflicts over pastures occur. In the discourse of modernization sedentary agriculture is perceived as a higher state of civilization than nomadism. The extensive utilization of marginal resources is superseded by intensification and increasing external inputs. Thus, it is not surprising that mountain farmers and nomads have been a prime target for 'development', which aims to reduce subsistence levels and 'traditional' lifestyles by integrating people from the periphery into the mainstream of nationstates. The mainstream debate on 'nomadism as a development problem' (Nomadismus als Entwicklungsproblem, Kraus 1969) supports sedentarization and economic integration as a strategy to modernize nomadic lifestyles.

\section{Wakhi and Kirghiz in the Pamirs - Social and Political Organization}

The people we know as the Wakhi actually call themselves Xik (and their own language as Xik zik). Wakhi is an ethnonym given by outsiders. Their neighbours and visitors identified the 'Wakhi' as the people living in Wakhan, until 1883 a principality on both banks of the upper Amu Darya and the Wakhan and Pamir Darya. Wakhan was under a hereditary ruler (mir) who controlled a territory in which both sedentary mountain farmers and Kirghiz nomads were living. Both communities paid him taxes and tributes in cash and kind. The Wakhi society consisted of two hierarchical strata. In the upper stratum were the ruling family (mir), some religious leaders (pir, sayid, xuja) and a few better-off families (sana, xaybari). The vast majority of the people (more than 95 per cent) belonged to the 'ordinary' people $(x i k)$, practised combined mountain agriculture and were obliged to deliver taxes and services such as duties of load-carriers and soldiers (Felmy and Kreutzmann 2004; Shahrani 1979). The societal setup has been affected by external and internal developments. Overall, it can be stated that the number of poor households has significantly grown in recent years (Figure 2). The geographic isolation of Wakhan and its distance from the domestic markets in Afghanistan has increased poverty and dependency in the Afghan Pamirs. 
Social structure and the process of pauperization among Wakhi
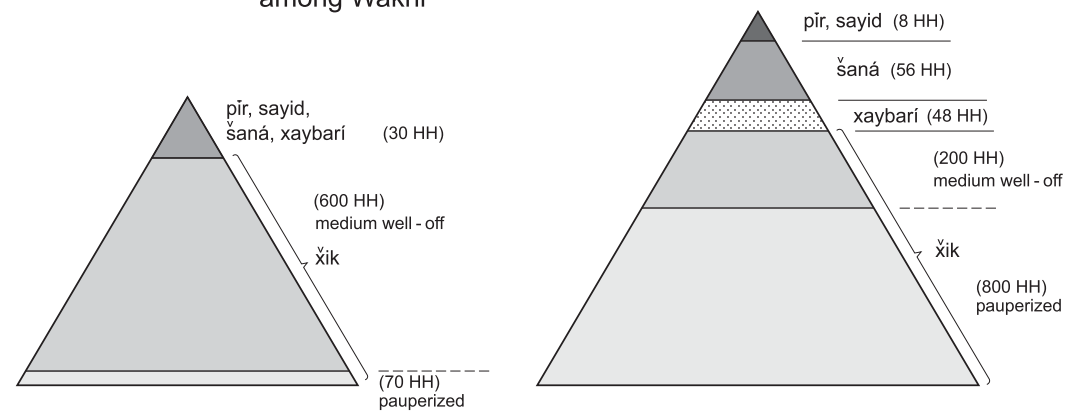

Source: data for mid-1970s according to Shahrani 1979a, data for 2003 according to Felmy \& Kreutzmann 2004 Design: H. Kreutzmann

\section{Figure 2: Social structure and the process of pauperization among the Wakhi}

Wakhan was no exception in Western High Asia, where many valleys or parts of them were principalities that had more or less strong links to their mighty neighbours: the Amir of Afghanistan, the Emir of Bokhara (later replaced by Tsarist Russia/Soviet Union), the Chinese Emperor and British India. The competition between these major players affected diplomatic relations, taxation, conscription policies, local politics and the economy, and finally resulted in the delineation of international boundaries and the end of independence.

The Kirghiz did not only live permanently under direct Wakhi administration. Their mobility enabled them to shift to grazing grounds with favourable conditions, i.e. low taxation and tolerable political pressure. The family histories of Kirghiz clans abound in stories of leaving some territories and starting a new life under different conditions, masters and/or protectors. However, the search for suitable pastures and low outside interference was always the guiding principle. Among themselves, the Kirghiz were organized along migratory groups headed by a camp elder (beg, khan) who normally represented the most affluent family. These were highly stratified communities, where the poorer yurts were occupied by mere shepherds at the service of the big owners of livestock (yaks, sheep, goats, Bactrian camels and horses). The leaders and the rich households profited from the system of renting out their livestock and giving it to shepherds for safe custody (amanat) (see Shahrani 1979). Kirghiz communities formed their own remote microcosms in the Pamirian pastures with relationships of varying strengths with their neighbours. The common goals were the defence of grazing grounds and the avoidance of outside interference.

As Wakhi and Kirghiz competed for the same resources, their relationships were not always amicable. Both communities were involved in a struggle for survival and sustaining their position where threats came from neighbours as much as from outside raiders, slave traders, representatives of the administration, conscriptors and tax officials. 


\section{Demographic Trends}

Demographic analysis shows an increase of population from the nineteenth to the twenty-first century almost everywhere in High Asia. Only major disasters, crises and/or exodus account for procrastination in this pattern. The same applies to the Wakhi people. An early population peak was reached around 1880 when about 6,000 people were estimated in the principality/mirdom of Wakhan. Shortly afterwards, a major crisis occurred. The geopolitical confrontation between British India and Tsarist Russia during the 'Great Game', as well as the Islamization and expansion programme of the Afghan Amir, threatened the autonomy of the small principalities in the Hindukush, Pamir and Karakoram. Wakhan was one of the cases (together with Shughnan and Roshan amongst others) where rulers were taken hostage by one or the other party. In 1883, the mir of Wakhan, Ali Mardan Shah, organized a preventive exodus for his family, and about a quarter of the population took refuge in his father-in-law's territory in Chitral. Subsequently, his fear materialized and Wakhan was divided into two territories, like other principalities, along the Amu

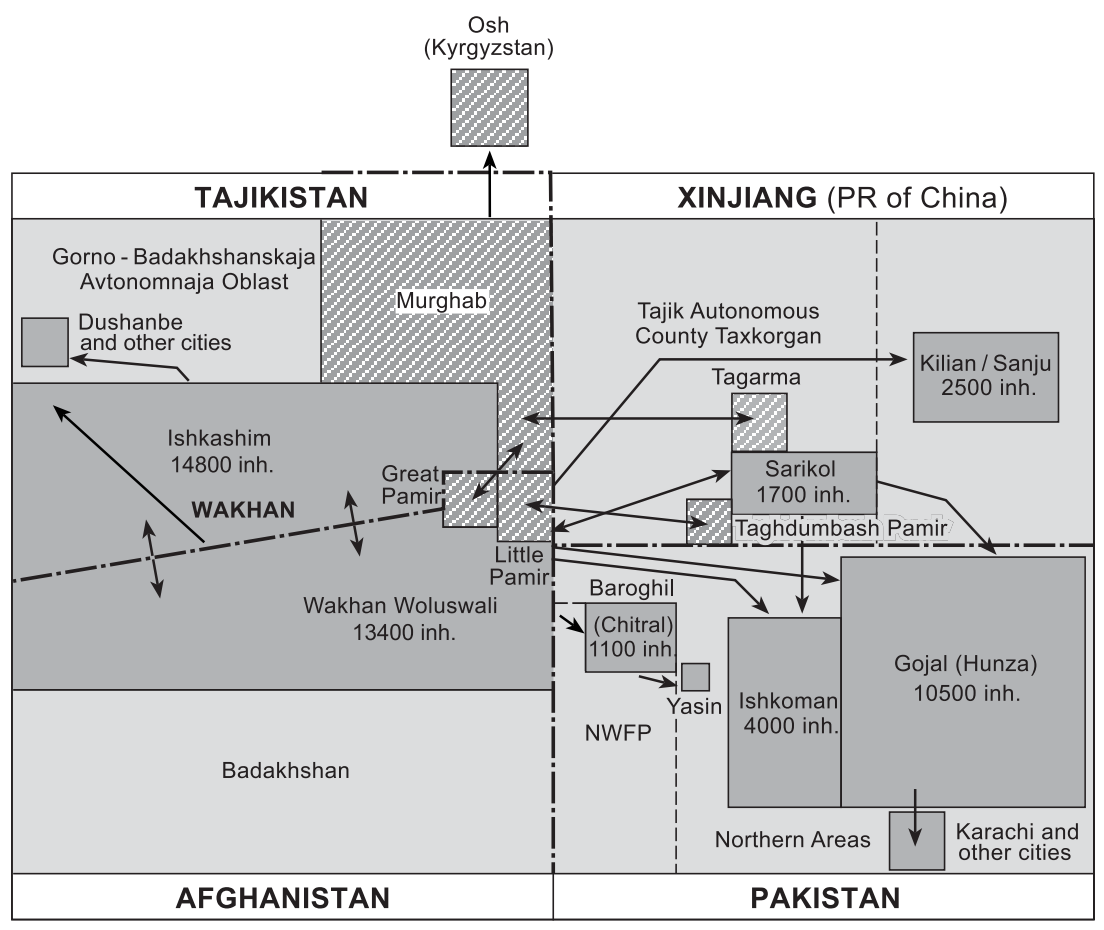

250 Wakhi inhabitants

250 Kirghiz inhabitants

Design: H. Kreutzmann

Figure 3: Population movements and establishment of settlements and pastoral camps of the Wakhi and Kirghiz across borders in the Pamirian Knot 
Darya river (Oxus). In the aftermath, the northern territory was controlled by Russia, whereas the southern territory became an extension of Afghanistan's territory. The panhandle-shaped, so called Wakhan strip was created as a buffer zone between Russia and British India, as the superpowers of the time avoided having common boundaries in any place. The artificial boundaries were laid down by the end of the nineteenth century and remain in place today. The division of Wakhan led to a refugee crisis, with numerous victims (the population of Wakhi decreased by one sixth). The low point was reached by 1900 and, since then, demographic trends have been pointing upwards (Kreutzmann 1996: 136). The 50,000 Wakhi of today reside in four different countries: Afghanistan, Tajikistan, Xinjiang (People's Republic of China) and Pakistan. Demographic patterns are linked to divided territories and mobility (Figure 3). The twentieth century appears to have been the age of migration. Refugees from Afghanistan still seek shelter and work in Chitral. Migrant workers from Tajikistan end up in Gojal (Hunza). They expect support from local Wakhi residents whose forefathers have taken refuge there for more than 200 years. The Gojali Wakhi participate in transborder trade with their Chinese neighbours. Thus, Wakhi communities are to be found in four countries of different political systems, market and state-controlled economies, and in regions of contrasting infrastructure, welfare and educational institutions.

Kirghiz nomads have been affected by the same geopolitical developments. Estimates about demographic trends are more complicated in nomadic contexts. The seasonal grazing grounds of Kirghiz were often split between different countries by the delineation of present international boundaries. While in early times border crossing was possible for them, it became almost impossible during the Cold War. The term of 'closed frontier nomadism' (Shahrani 1979) was coined to describe their case. The new border along the Amu Darya river became the most hermetically controlled boundary at the interface between the Soviet Union and Afghanistan. The border dispute between the USSR and China led to the introduction of the so called 'sistema' as late as the 1980s. The system identifies a demilitarized zone which includes a $30 \mathrm{~km}$-wide border strip with metal fences on both sides. Thus, communication and grazing across boundaries and within the 'system' became impossible. Kirghiz communities were forced to remain in their respective countries. The Eastern Pamirs of present-day Tajikistan are predominantly inhabited by Kirghiz, the same applies to the Little and Big Pamir of Afghanistan. China introduced a Kirghiz Autonomous District by the name of Kizil Su, while some Kirghiz live in the Tajik Autonomous County of Taxkorgan.

\section{Environmental Assets and Constraints}

For nomads, the extensive use of wide-ranging pastures is essential. From their perspective, any restriction to migration and the limitation of accessible pastures is perceived as an environmental crisis. In the case of high mountain nomadism, 
the principle of maximum utilization of natural pastures is linked to the grazing of flocks at high altitudes (above 3,500 $\mathrm{m}$ ) during the summer and keeping the herds on lower pastures (around 1,200 m) during the winter. The Kirghiz strategy in the Pamirs was based on such an approach. During winter, the urban oases of the Southern Silk Route or the Fergana Basin offered opportunities for keeping the herds on agricultural fields after the harvest. The animals scavenged for any remainders and grass while improving irrigated lands in the oasis through their valuable manure. At the same time, the Kirghiz practised business and trade before retreating to the high pastures for the summer. These times have long since passed. Basically, winter pastures are missing everywhere today. The expansion of cultivation in irrigated oases, the introduction of stationary livestock-keeping and the increase in urbanization has led to an exclusion of nomadic entrepreneurs and their herds. Furthermore, political changes such as collectivization and central planning affected the long-established patterns of animal husbandry for all previously involved groups. In summary, accessible pastures are found nowadays only where modernized agriculture has failed or where political circumstances have allowed for their preservation, generally in remote locations above 3,500 m.

For the Wakhi mountain farmers, their situation has been substatially affected by irrigated crop farming. The expansion of households predominantly engaged in agriculture resulted in a higher demand for natural resources which are rather limited. Although there is competition with Kirghiz nomads for high pastures during the summer, the real constraint occurs in winter. With little land left to the villagers (on average less than one hectare per household), fodder production in the homesteads competes with food production. Crop farming at the upper altitudinal limit not only faces climatic vagaries but gives comparatively poor returns and offers little scope for expansion. Consequently, animal husbandry gains overall importance in the regional production system. Any changes to animal production strategies here are of major consequence for the livelihood conditions of the people concerned.

\section{Sociocultural Challenges}

Below I present five examples of external interventions aimed at resturcturing the livestock sector. The complexity of sociocultural problems and the manifestation of transformation processes in societies with economies based on pastoralism vary from region to region. However, all examples show how political conditions have affected the livelihood conditions of the Kirghiz and Wakhi in Western High Asia during the twentieth century with noticeable effects up to the present day.

\section{(i) Soviet Sedentarization Programmes and Recent Developments in Middle Asia}

As the majority of the Pamirs are located within the Gorno-Badakhshan Autonomous Oblast (GBAO) of the Tajikistan Republic, the people living there were involved in the sedentarization process of nomads during the Stalinist modernization 
programmes in the 1930s. Autonomous republics and districts were created in order to uplift the pre-modern layers of society; hence, the Autonomous Soviet Socialist Republic of Tajikistan had been carved out as a new entity. At this stage, nomadic production and lifestyle was declared backward and intolerable. Consequently, the system of pasture utilization under the Kirghiz (begs) was replaced by kolchoz (kollektivnoe chozjajstvo = collective economy) and sovchoz (sovetskoe chozjajstvo = Soviet economy) settlement-centred seasonal migration of herds. Collective and/or Soviet state farming meant that winter quarters were established, from where the

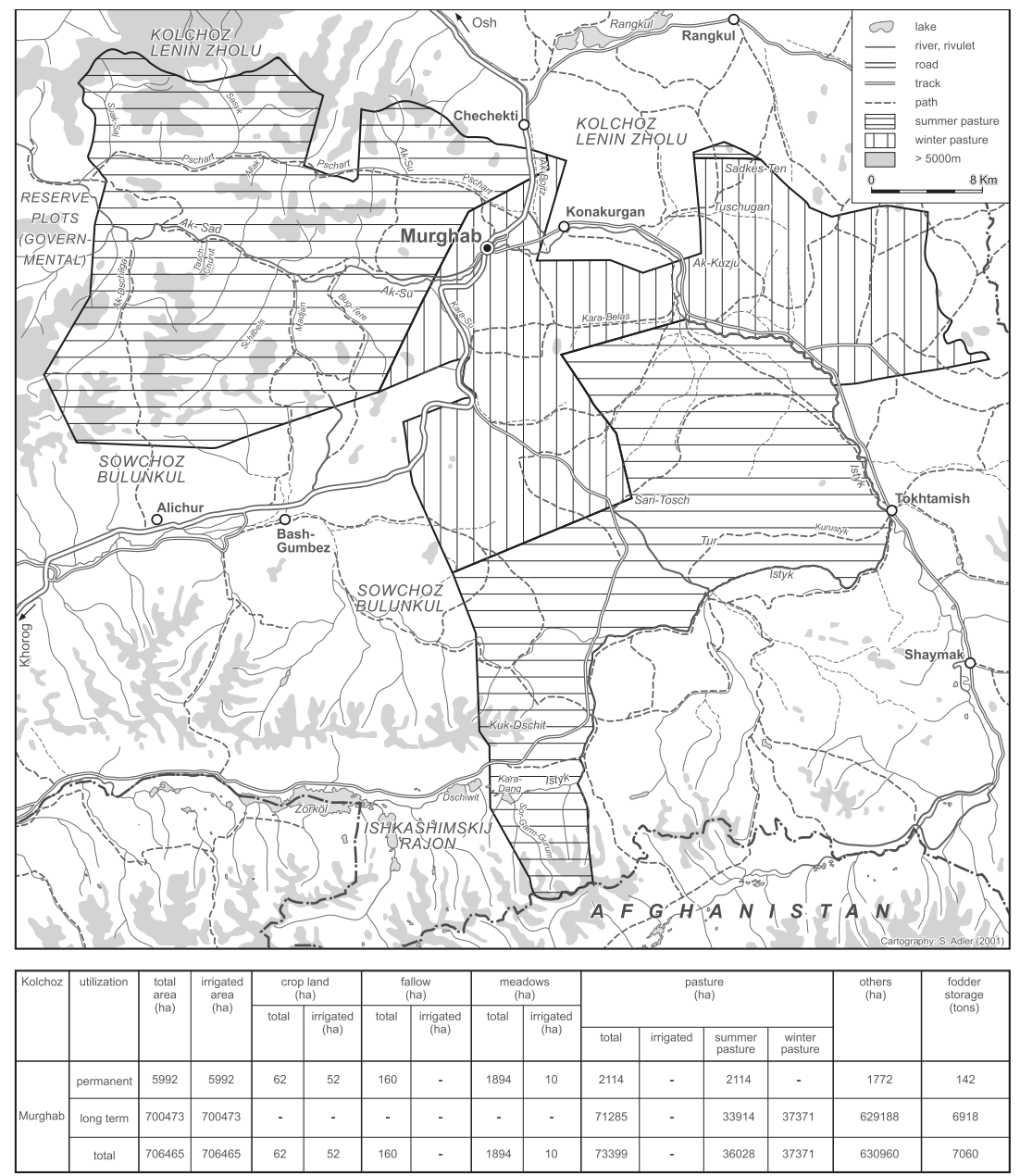

Source: own design based on Kolchoz map of 1964

Figure 4: Summer and winter pastures of the Kolchoz Murghab, Murghabskij Rajon, Tajikistan 
collectivized herds were brought to pasture. The flocks were controlled by shepherds of the respective units, while during summer, yurt encampments remained as filial branches of the unit. Where it seemed feasible, fodder production was increased and attempts to improve the breeds and health conditions of the herds were made. Permanent winter stables with adequate infrastructure, veterinary treatment and sufficient fodder contributed to a new settlement cell which resembles some aspects of the Pamirian pastoralism in present times.

In the Eastern Pamirs nowadays, Kirghiz shepherds and a few Wakhi keep yak, sheep and goat herds around well-established supply stations. From there, they undertake seasonal migrations to the higher elevated summer pastures. Basically, Kirghiz nomadism was converted into a form of mobile animal husbandry under the conditions of collective resource management. All the same, Wakhi combined mountain agriculture was adjusted to the prevalent socioeconomic setup.

Under Soviet rule, Tajikistan's economy was completely integrated into the centrally-planned Union system. This had significant effects even on the remote mountain areas, as the case of Gorno-Badkhshan reveals. The Soviet state-run economy had selected the Eastern Pamirs primarily as a sheep and yak-producing region (Figure 4). All other agricultural activities prevalent before were subordinated to the dominant livestock sector. Irrigated village lands formerly utilized for grain production were converted into fodder production zones. The Wakhi members of sowchos roi kommunizm in Rajon Ishkashim kept a sizeable yak herd in the upper parts of the Amu Darya valley and in Khargushi Pamir. Even in low-lying Wakhi villages, alfalfa and fodder crops had replaced barley, wheat and beans. Their whole agricultural system was devoted by decree to animal husbandry, because all other food supplies were imported from outside. Even high-protein fodder (50 tons) was brought in annually from as far as Kyrgyzstan to sustain a herd of 450 yaks in the Pamirs throughout the year.

With the independence of Tajikistan and the transformation process, individual ownership of land (1996-99) and cattle were reintroduced. Yak herding is now organized through the farmers' associations; the shepherds keep 70 per cent of the production, while the rest belongs to the association. The Wakhi of Ishkashim still control a herd of 288 yaks besides 50,400 sheep and goats. In neighbouring Rajon Murghab with more than 3,100 households ( 85 per cent Kirghiz), nearly 15,200 yaks and 45,900 sheep and goats were kept in 2008. ${ }^{1}$ The majority of herds are controlled by private farmers' associations and one 'cooperative farm', an institution developed out of the old kolchoz and gozchoz state farms.

After the failure of the Soviet model of modernization, we experience a reversal of the path of 'development'. Two to three generations ago, the Kirghiz nomads and Wakhi mountain farmers were expropriated and their property was collectivized. Consequently, they became state employees. But now resources and property have been redistributed. The present socioeconomic process of transformation has forced the majority of the Kirghiz and Wakhi to follow a 
subsistence strategy based on crops and livestock. It appears to be a return to their fathers' livelihoods, but global and regional conditions are very different. Income levels are much lower and it remains to be seen whether the present strategy can be sustained. The level of insufficiency and depression is high, as many young people out-migrate and seek low-level employment, mainly in Russia.

The previous interrelationship of Pamirian pastoralism and supply structures of the Soviet Union became obsolete. Nowadays, no fodder supply can be transferred across state borders. Even the Kirghiz residents of Sary Mogol (Alai valley, Kyrgyzstan) who were counted as belonging to the Eastern Pamirs of Tajikistan had to decide by 2004 whether they wanted to be included in Kyrgyzstan or not. They opted for Kyrgyzstan and remained in Sary Mogol. Consequently, the pastoral system in the Eastern Pamirs has changed. Households depend on local resources just as much as they need the additional income from migrants' remittances, entrepreneurship, services and trade.

\section{(ii) Competition between Nomads and Mountain Farmers in the Pamirs (Sarikol,} People's Republic of China)

The Taxkorgan or Sarikol (the name of the former principality) area comprises three different ethnic groups (besides a Han Chinese and Uighur minority): Sariqoli, Wakhi and Kirghiz (here less than 5 per cent of the population). The former two groups (81.75 per cent of the inhabitants) follow a combined mountain agriculture composed of crop cultivation and animal husbandry with seasonal utilization of Pamir pastures, whereas the Kirghiz specialize solely in livestock. All three groups traditionally move their flocks within the Taghdumbash Pamir and had been tributary to the mir of Hunza, who exercised control over these pastures until 1937. While the Kirghiz lived in the higher elevations, the Sariqoli approached from the northern low-lying villages (see Kreutzmann 1996, 2003). The only permanent settlement was founded by the Wakhi, who were stranded as refugees from Afghanistan, in Dafdar (3,400 m) in the heart of the Taghdumbash Pamir about a century ago, with the consent of the Chinese authorities. All three groups compete for the fodder resources there.

After the Chinese Revolution in 1949 and the formation of the Tajik Taxkorgan Autonomous County in 1954, collectivization took place and rural communes (gungshe) were established in the villages. The socioeconomic model from the neighbouring republics was implemented by Chinese revolutionaries and their Soviet advisors. Basic infrastructural assets were provided to all communities of the Taghdumbash Pamir.

In post-revolutionary times, the number of livestock increased by a factor of 4.75 up to 128,800 heads in 1984 . During the following decade, growth slowed down and in 1994, the number of livestock amounted to 147,586. Natural grazing provides the most important local resource utilized by animal husbandry: the grasslands extend to 408,000 ha (6.09 million $m u)$ of which 97.6 per cent belong to natural grazing, while $8,710 \mathrm{ha}(0.13$ million $\mathrm{mu})$ are irrigated meadows . More 
than two thirds of the economic turnover of Taxkorgan County derived from animal husbandry in the 1990s. Presently, only 15 per cent of the County GDP is contributed by the primary sector (Yibulaying 2009).

Modernization has reached the Wakhi and Kirghiz the Chinese way. Economic liberalization and political authoritarianism remain the conceptual basis. Consequently, Taxkorgan's location along the Karakoram Highway (KKH) and the 'open-to-the-West' strategy in the Kashi Prefecture has changed the local economy. Kirghiz and Wakhi participate in tourism and trade-related activities and maintain their pasture utilization as the economic backbone and security measure.

\section{(iii) Kirghiz Pastoralists in Kara Köl}

Earlier on, the Kirghiz of Kizil Su followed a long-distance nomadic migration cycle between the summer grazing grounds in the Pamirs and the irrigated oases of the mountain forelands. They spent the winter occupied with herding and various other businesses in the towns of Kashgar and Yarkand. The usual pattern has been abridged within the last 50 years (Figure 5). Nowadays the Kirghiz nomads and their herds are confined to the Pamir regions all year round. Only for marketing purposes do they leave their mountain abodes and travel on foot with their flocks or on rack-body trucks down to the Sunday markets of Kashgar and/or Yarkand. Thus, the herds cover the distance of $280 \mathrm{~km}$ easily and without great loss of weight.

The pasture system has been adjusted to changed frame conditions. On average, the herds of the Kara Köl Kirghiz consist of 1.5 horses, 1.4 donkeys and 2.5 Bactrian camels. These animals are primarily required for transportation and travelling purposes. The additional livestock amounts on average to 12.2 yaks, 98.2 sheep and 40.1 goats. In comparison, in 1976, the people's commune of Subashi (Karakul) owned only 0.5 horses, 0.3 camels, 3.5 yaks and 74.9 sheep and goats per household. The total number of livestock in this period amounted to some 10,300 animals. Besides state ownership of flocks, private property rights for a limited number of animals had been assured for the pastoralists. The 'carrying capacity' - as of accessible pastures was estimated at 40,000 animals; by 1991, the number of heads had passed the 30,000 mark and has now crossed this threshold significantly, with presently more than 50,000 animals. In comparison with the overall livestock development in the Aqto division, where livestock numbers grew by a factor of 1.3 and cattle numbers by a factor of 1.65 from 1976 to 1991, the growth in Kara Köl is out of proportion. In the remote, high-altitude yak and sheep-breeding area, the livestock numbers grew three times faster. In this area the relaxed attitudes of the Chinese authorities towards agricultural and livestock production, especially since the reforms of 1978, have led to an increased market orientation. The quality of pastures was improved by irrigation and fencing of meadows. Grass is cut by scythe and winter fodder is stored to cover the long period of meagre natural grazing in the winter settlement (kishlok) of Subashi. 

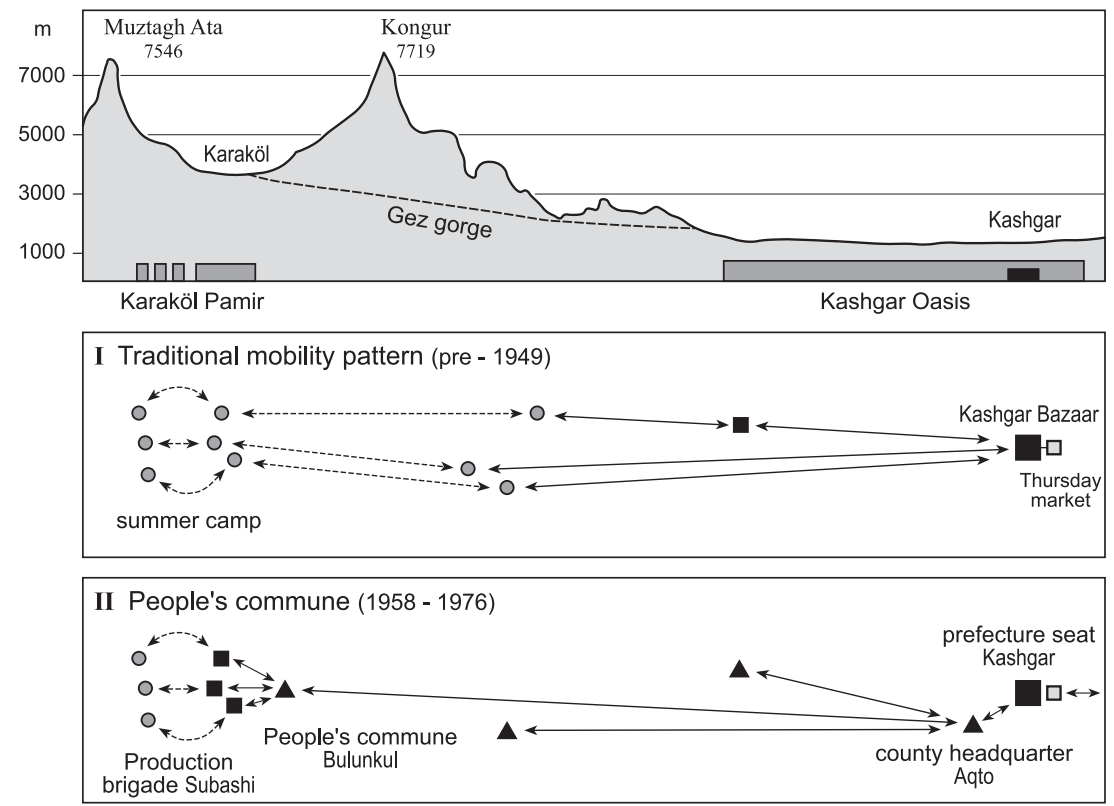

III Production responsibility system (post - 1978)
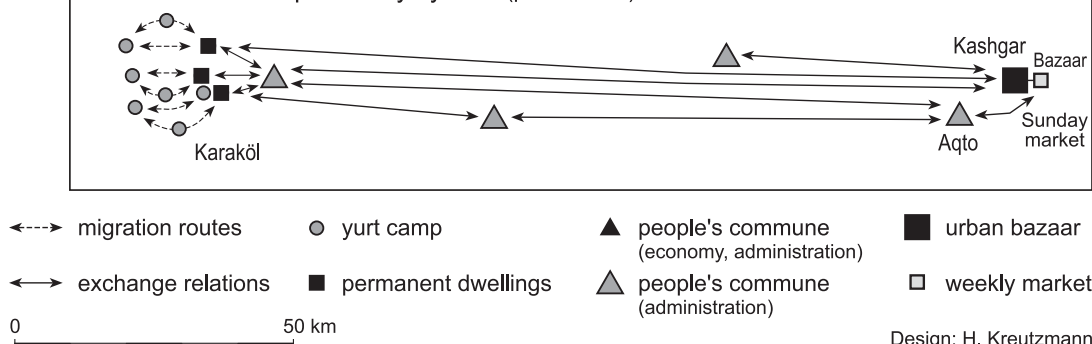

$\square$ urban bazaar
$\square$ weekly market

Design: H. Kreutzmann

Figure 5: Transformation of Kirghiz social organisation and pastoral strategies in Kara Köl, Xinjiang (People's Republic of China)

Subashi $(3,600 \mathrm{~m})$ is equipped with familiar infrastructures and with a veterinary post controlling the quality and health of the animals. Harsh environmental conditions disguise the fact that the animals raised on these nutritious pastures compete very well on the profitable markets in the urban oases along the Southern Silk Route (Tarim basin). The Kirghiz are respected as one of the most affluent livestock-breeding communities of the region. 


\section{(iv) Kirghiz Exodus from the Afghan Pamirs}

The Great and Little Pamir within the Wakhan Woluswali of Badakhshan Province (Afghanistan) were studied extensively up to the repeated and apostrophized 'last exodus' of the majority of Kirghiz nomads to Pakistan in 1978. Their fate is one of the more prominent cases where border delineation has interrupted traditional migration patterns (Felmy and Kreutzmann 2004; Shahrani 1979).

In 1978, nearly all of the Kirghiz (inhabitants of 280 yurts) fled to Pakistan. Rahman Kul alone had to leave behind 16,000 sheep and goats, more than 700 yaks, 15 horses and 18 Bactrian camels, while the whole community of the Afghan Pamirs had possessed more than 40,000 animals. In comparison, the majority of the Wakhi managed on a much lower economic level. Wakhi farmers utilizing the Pamirs for summer grazing tried to compete with rich Kirghiz nomads who controlled most of these Pamirs. Some impoverished Wakhi took up jobs as shepherds for Kirghiz herd owners. Eventually, they themselves turned to nomadic strategies.

When the Kirghiz left the Pamirs, they left almost all of their wealth behind. Only 6,000 animals could be taken across the high passes to exile in Pakistan, and none from there to Turkey. In August 1982, Rahman Kul migrated with his 1,132 Kirghiz followers to Eastern Anatolia. The Kirghiz community was established in Kurdish territory as part of a government resettlement scheme which provided each household with ten sheep and goats as well as three heads of cattle. Rahman Kul became the leader of the village community in Ulupamir Köyü $(1,800 \mathrm{~m})$ where he died in 1990 and was succeeded by his eldest son. Presently, this community has grown to 2,000 members following a lifestyle of sedentary agriculture and animal husbandry, with herds of 7,000 sheep, 1,000 goats, 6,000 cattle and 70 horses. In recent years, there was no sign of their leaving this part of Turkey for an uncertain future in High Asia.

A small group of 200 Kirghiz refused to follow their khan to exile and returned to the Afghan Little Pamir from Pakistan by October 1979. Under the leadership of Abdurrashid Khan, they established themselves in Soviet-occupied Wakhan and have remained there ever since. The community had grown to 102 yurts in Pamir-e Kalan (Great Pamir) and 135 yurts in Pamir-e Khurd (Little Pamir) by 1999. Their number of yaks totals around 1,400 compared to nearly 9,000 sheep and goats, 160 horses and 90 Bactrian camels. Any form of animal husbandry has been limited to subsistence strategies in recent years, as traditional exchange routes have been interrupted due to adverse political conditions. Presently, the Kirghiz are engaged in livestock breeding and in limited barter trade with entrepreneurs from neighbouring Hunza in Pakistan (Figure 6). The itinerant traders supply basic necessities in exchange for yaks and sheep and livestock products such as wool, hides, yak tails and qurut (dehydrated butter-milk). Nevertheless, external humanitarian aid is regularly needed for basic food supplies. Abdurrashid Khan remembers the period of Soviet occupation in the Afghan Pamirs as the most comfortable period of his life. Prospects for the future are bleak and negotiations were started with the government of Kyrgyzstan. Up to now, the majority of the Kirghiz refuse to leave the fertile Pamir pastures. Among all the Kirghiz groups studied, the least amount of change to livelihood strategies has 




Salt trade with Chitral was an important source of income in former times. Salt trade ceased with the exception of salt from Kalafgon. Only a few Wakhi from Sarhad work for Kirghiz today. Source: own fieldwork 2003

(C) H. Kreutzmann

Figure 6: Exchange relations across borders - Wakhi and Kirghiz interdependencies

occurred here. An elementary school was established only recently (Callahan 2006), but no dispensary or hospital is located in the Afghan Pamirs, nor are there any bazaars or shops. Bartering of livestock products and animal husbandry, organized through a migratory cycle between winter and summer camps (sometimes with an intermediate camp), continues to be the prime occupation of this community.

\section{(v) Wakhi Mountain Farmers in Gojal (Hunza, Pakistan) and Wakhan (Afghanistan)}

There could be no bigger contrast than that between the Wakhi mountain farmers of Pakistan and Afghanistan. High mountain farmers in Wakhan are forced to adopt a strict subsistence strategy as they are hardly able to make a living from their fields and pastures (Felmy and Kreutzmann 2004). The old capital of the Wakhi, Qala-e Panja, is located in Afghan Wakhan. The ruin of the fort, located within the agricultural fields, symbolizes the dwindled autonomy and there is little state authority to be felt. Before the Afghan crisis, bureaucrats from Kabul were sent to Khandut, the administrative centre of Wakhan with a small bazaar. The spiritual authority of Wakhan, Pir Shah Ismail, replaced outside players and was only accountable to the commanders of the Northern Alliance. He is currently the influential political representative for the Kabul government and active counterpart for non-governmental organizations. Locally, the situation is characterized by production strategies which have been known for a long time. However, the 1,000 
plus Wakhi households in Wakhtan have no one to trade with now. This critical element of the old Wakhi livelihood system being missing (the non-agrarian part of the household's income), their subsistence is seriously undermined. Regularly, people from here were crossing the border into neighbouring Pakistan to offer livestock and their personal services as wage labourers in exchange for dearlyneeded flour. Pakistan closed the borders; migrants now seek employment within Afghanistan. Here we find mobility again as a coping strategy for crises. Without these opportunities, survival in an isolated Wakhan would be out of the question.

To a lesser degree, impoverished Wakhi communities prevail in Pakistan: in Baroghil (Yarkhun Valley, Chitral), Darkot (Yasin) and Ishkoman. In Gojal (Hunza Valley), an exceptional development took place. The Wakhi residing here have significantly exercised the options offered by the Aga Khan Development Network (AKDN) and those resulting from migration. As a long term strategy, the AKDN tried to improve the infrastructure by setting up a health network, educational institutions and rural development projects, complementing the efforts by the government of Pakistan. Nearly all boys and girls now attend schools; many have participated in advanced training, which has resulted in professional careers far remote from dependency on agriculture. Many Wakhi are residing and working in the urban centres of Pakistan and some are overseas migrants.

Animal husbandry as part of a combined mountain agriculture has ceased to be the main livelihood strategy. Cash crop production of potatoes promises much higher returns and is less time-consuming. Access to the Karakoram Highway as the major traffic artery linking Pakistan with China became instrumental as an additional asset. The Gojali Wakhi are involved in Pak-China trade as much as in commercial and professional enterprises in Pakistan.

The case of Gojal shows that outside intervention and subsidies succeeded in supporting some communities and households that could expand their sources of income. Development efforts have contributed among other factors to a more diversified foundation for survival in harsh environments (Kreutzmann 1996, 2005, 2006). Comparable measures of external support could only be found in the former Soviet Union, where basic infrastructure was funded from the centre and provided to the remotest locations. A similar strategy was followed by China.

\section{Conclusions}

The case studies have shown how in a similar ecological setting, the welfare of mountain farmers and pastoralists alike is significantly influenced and shaped by external interventions. Over time, spatial utilization strategies have been transformed in accordance with the shift of political players and the replacement of stakeholders. Earlier patterns of evasion in the form of leaving spheres of influence in search of safer abodes have become approaches of limited success or overall inaccessible strategies. Consequently, adaptation to existing rules and acceptance of 
influential actors are observable patterns of mountain farmers and pastoralists in the Pamirian Knot. In the majority of cases, marginalization in a shrinking space has occurred, although in a few cases living standards improved significantly. Modernization has taken place as a mixed blessing. Nevertheless, the path has been followed, and adjustments to it are the challenges of the present and the future.

\section{Notes}

1. I gratefully acknowledge the provision of most recent data by Tobias Kraudzun.

\section{References}

Barfield, T. 1993. The Nomadic Alternative. Prentice Hall, Englewood Cliffs.

Braudel, F. 1972. The Mediterranean and the Mediterranean World in the Age of Philip II, Vol. I. Collins, London.

Brower, B. and B.R. Johnston. eds. 2007. Disappearing Peoples? Indigenous Groups and Ethnic Minorities in South and Central Asia. Leftcoast Press, Walnut Creek.

Callahan, T. 2006. Maktab-i Pamirs: Prospects and Problems in Building Schools in the Afghan Pamirs (unpublished report).

Curzon, G.N. 1896. 'The Pamirs and the Source of the Oxus', The Geographical Journal 8: 15-54, 97-119, 239-64.

Dor, R. and C. Naumann 1978. Die Kirghisen des afghanischen Pamir [in German, The Kirghiz of the Afghan Pamir] Akademische Druck- und Verlagsanstalt, Graz.

Ehlers, E. and H. Kreutzmann. 2000. 'High Mountain Ecology and Economy. Potential and Constraints'. In High Mountain Pastoralism in Northern Pakistan, eds., Ehlers, E. and H. Kreutzmann. Steiner, Stuttgart, pp. 9-36.

Felmy, S. and H. Kreutzmann 2004. 'Wakhan Woluswali in Badakhshan. Observations and

Reflections from Afghanistan's Periphery', Erdkunde 58(2): 97-117.

General Staff India ed. 1907. Military Report on Kashgaria, prepared in the division of the Chief of the Staff. Intelligence Branch, Simla.

Hauner, M. 1989. 'Central Asian Geopolitics in the Last Hundred Years: A Critical Survey from Gorchakov to Gorbachev', Central Asian Survey 8: 1-19.

1992. What is Asia to Us? Russia's Heartland Yesterday and Today. Routledge, London.

Humphrey, C. and D. Sneath. 1999. The End of Nomadism? Society, State and the Environment in Inner Asia. Duke University Press, Durham.

Huntington, E. 1905. 'The Mountains of Turkestan', The Geographical Journal 25: 22-41, 139-58.

1907. The Pulse of Asia. A Journey in Central Asia Illustrating the Geographic Basis of History. A. Constable, London, Houghton Miffin, Boston.

Huntington, E. and S.W. Cushing. 1924. Principles of Human Geography. John Wiley, New York, London. 
Kraus, W. 1969. Nomadismus als Entwicklungsproblem. Bochumer Symposion 14./15. Juli 1967 [in German, Nomadism as a problem for development. Bochum symposium July14-15, 1967]. Bochumer Schriften zur Entwicklungsforschung und Entwicklungspolitik 5. Bertelsmann, Bielefeld.

Kreutzmann, H. 1996. Ethnizität im Entwicklungsprozeß. Die Wakhi in Hochasien. [in German, Ethnicity in development. The Wakhi of High Asia] Dietrich Reimer, Berlin.

2003. 'Ethnic Minorities and Marginality in the Pamirian Knot. Survival of Wakhi and Kirghiz in a Harsh Environment and Global Contexts', The Geographical Journal 169(3): 215-35.

2005. 'Pastoral Practices and their Transformation in the North-Western Karakoram', Nomadic Peoples 8(2): 54-88.

2006. 'High Mountain Agriculture and its Transformation in a Changing Socioeconomic Environment'. In Karakoram in Transition. Culture, Development, and Ecology in the Hunza Valley, ed. H. Kreutzmann. Oxford University Press, Karachi, Oxford, pp. 329-58.

Kuropatkin, A.N. 1882. Kashgaria (Eastern or Chinese Turkistan): Historical and Geographical Sketch of the Country; Its Military Strength, Industries and Trade. (translated from the Russian by W.E. Gowan), Calcutta. Translation of Kuropatkin, A.N. 1879. Kashgariia: Istoriko-geograficheskii ocherk strany, eia voennyia sily, promyshlennost i torgovlia. St. Peterburg.

Sahni, K. 1997. Crucifying the Orient. Russian Orientalism and the Colonization of Caucasus and Central Asia. White Orchid Press, Bangkok.

Scholz, F. 2002. Nomadism and Colonialism. A Hundred Years of Baluchistan 1872-1972. Oxford University Press, Karachi.

2008. Nomadism. A Socioecological Mode of Culture. International Institute for the Study of Nomadic Civilizations, Ulaanbaatar.

Shahrani, M.N. 1979. The Kirghiz and Wakhi of Afghanistan. Adaptation to Closed Frontiers. University of Washington Press, Seattle and London (reprinted 2002).

Skrine, C.P. and P. Nightingale. 1973. Macartney at Kashgar. New Light on British, Chinese and Russian Activities in Sinkiang (1890-1918). Methuen, London.

Yibulaying, D. 2009. 'Developing Eco-tourism in Border Areas and Promoting SocioEconomic Improvement in Mountain Areas. The Case of Taxkorgan County'. In Integrated Tourism Concepts to Contribute to Sustainable Development in Mountain Regions, eds., Kreutzmann, H. et al. InWEnt Publications, Feldafing (in print).

Hermann Kreutzmann is Chair of Human Geography and Director of the Centre for Development Studies at the Institute of Geographic Sciences, Freie Universitaet Berlin. His main research interests are: minority issues, migration, pastoralism, irrigation and water management in South and Central Asia, political geography and development theory. Address: Institute of Geographic Sciences, Department of Earth Sciences, Freie Universitaet Berlin, Malteserstr. 74-100, House K, D-12249 Berlin, Germany. Email: h.kreutzmann@fu-berlin.de 